\title{
Morpho-Metric Analysis of Kunah Khad, Himachal Pradesh
}

\author{
Dr. Sanjay Kumar \\ Associate Professor, Department of Geography, Govt.College Hamirpur. \\ Acknowledgements: University Grants Commission New Delhi
}

\begin{abstract}
Water is vital to life without which no living bodies can survive. It is also indispensable for economic prosperity and overall development of a nation. As such, water is considered as a prime natural resource, a basic human need and a valuable national asset. Due to the rapid increase in the population, demand for food increased and as a result to increase the production, irrigation activities spread and demand for water increased. The water is not automatically available because its renewability is governed by the ecological process that gives stability to the water cycle. The seasonal rainfall last for few days in most part of the country. This seasonal rainfall has mad impact on agriculture and social life. Frequent droughts have made it necessary to employ various water conservation methods; including traditional ones. Availability of water is highly uneven in terms of both space and time. Water management need grater understanding of the area in which it flows. It may be useful to consider water management is possible only if we manage the land properly in which water flow through channels. Land can be managed properly only when we develop man. Man can not be developed without land and land cannot be developed without water. All these three factors are interrelated to each other and dependent on one another. Therefore we should have an area which should have some common properties in relation to land water and human resources or physical \& cultural properties. For the purpose we require a watershed. A watershed is an area having common drainage. This means that the rain water falling on an area within a ridge line will flow out of this area through a single point. In a watershed the area is inter- dependent in terms of physical \& cultural aspects. In a watershed soil type, slope, vegetation cover, grass cover, drainage and its chrematistics, geology and other physical chrematistics are need to be studies with the cultural aspects of the region. If a watershed is well managed for the water, it is best managed for all the other resources. In the present study the physical and cultural aspects of Kunah Khad is studied on the basis of primary and secondary data.
\end{abstract}

\section{Introduction}

A sum total of all physical, chemical, biological and social factors which constitute our surroundings is the environment. Each element of these surroundings on which human being depends in order to develop a better life is a resource. Management of these resources is vital for human survival. Degradation of the resources will not only cause poverty in the present generation but will also jeopardize opportunities for future generation. The management of any resource is only possible when one know every thing about that resource. Environmental monitoring and management is necessary in order to have a development without destruction, a development which is eco- friendly and sustainable in nature. The sustainable development which is the major goal of any developmental planning, can be achieved only when the natural environment, its carrying capacity and potentials, are given due attention. This is possible through proper monitoring and management of different kinds of natural resources such as land, water, mineral, flora and fauna and the entire biospheric component. This is not an easy task. Besides, if the size of the area is large, than the job becomes complicated. This therefore calls for micro- level planning. The micro - level planning is the planning at the sub regional level. There are different indicators and parameters to determine the areal unit's best suited to micro level planning. However, what is most important in this context is the homogeneity in terms of natural endowments and social and economic environment. Planning cannot succeed if this homogeneity is not built into the process of regional planning. It has been established that river basins, catchment areas or for that matter watershed provide the areal units best suited for environment monitoring as well as for management and development.

The concept of watershed planning is quit old and goes back to 1930's when T.V.A was established in USA. In India the concept at watershed as a small unit for management and development of land and water resources was initiated by shri ( Late ) Y.P.Bali in 1974 ( Gautam ,N.C, Dr V Raghavswamy, Dr R. Nagaraga , Dr. G.R.Shankar, Dr P.R Mohan 1995 concept and delineation of watershed for development, Annals, National Association of Geographers India, Val.15 No 1 PP. 53.74 ) .After the ministry of Agriculture, Govt. of India initiated the programme of soil and water conservation adopting watershed as a planning unit, this programme has gained momentum and on this basis presently watershed form the basis of presenting natural resources data for effective planning and sustainable development of land and water resources .

In India, perennial rivers are the main source of surface water. A systematic study at the river system involving river morphology, drainage characteristics etc, is required for its proper utilization. The delineation 
and study of the small hydrological units namely watershed and their linkage with the higher categories such as catchments, river basins etc, are important at national level

\section{Problem To Be Investigated}

Water has suddenly become a favoured subject for seminars and conferences all over the world. A great deal has been said on the water resources in India also. A large part of our water resources is used in agriculture but in an inefficient manner. Land water and energy are the basic needs for any development. Out of these, water, has become the matter at concern in almost all the countries. The central theme in the eighties was water, because of the major droughts faced by many countries. The water crisis occupied the centre stage of Indian planning and disturbed all the previous planning's. The water is not automatically available because its renew ability is governed by the ecological process that gives stability to the water cycle. The seasonal rainfall last for few days in most part of the country. This seasonal rainfall has mad impact on agriculture and social life. Frequent droughts have made it necessary to employ various water conservation methods, including traditional ones.

Water is a prime natural resource, and a precious natural asset .It is a basic human requirement. Availability of water is highly uneven in terms of both space and time. Water management need grater understanding of the area in which it flows. It may be useful to consider water management is possible only if we manage the land properly in which water flow through channels. Land can be managed properly only when we develop man. Man can not be developed without land and land cannot be developed without water. All these three factors are interrelated to each other and dependent on one another. Therefore we should have an area which should have some common properties in relation to land water and human resources or physical \& cultural properties. For the purpose we require a watershed. A watershed is an area having common drainage. This means that the rain water falling on an area within a ridge line will flow out of this area through a single point. In a watershed the area is inter- dependent in terms of physical \& cultural aspects. In a watershed soil type, slope, vegetation cover, grass cover, drainage and its chrematistics, geology and other physical chrematistics are need to be studies with the cultural aspects of the region. If a watershed is well managed for the water, it is best managed for all the other resources.

STUDY AREA Kunah khad is a tributary of Beas on its left bank Kunah khad covers an area of $346.25 \mathrm{sq} . \mathrm{km}$. It extended from $31^{\circ} 34^{\prime} 17^{\prime \prime} \mathrm{N}$ latitude to $31^{\circ} 46^{\prime} 36^{\prime \prime} \mathrm{N}$ latitude and $76^{\circ} 21^{\prime} 59^{\prime \prime}$ east longitude to $76^{\circ} 40^{\prime} 31^{\prime \prime}$ east longitude. Kunah Khad runs in east west direction. But it follows in zigzag path in between it runs in south west direction after its origin then runs in east west direction and then follows north west direction before its confluence with the Beas River. Kunah Khad watershed covers an area of 345.889 sq. kms. Kunah Khad originates at Awah Devi at an elevation of 1132 metres above mean sea level; it joins the Beas River at Bilkeshwar at an height of 480 meters above means sea level. Kunah Khad is joined by many tributaries some major right hand tributaries are Gosoti khad, rain khad, Hathli kahad and sukar khad, Jhaniari khad, Badh khad. Kunah khad is known as life line of the Hamirpur Distt . It drains area of Hamirpur distt. , it is the main sources of water of the people of Hamirpur distt about population depends upon this khad for water kunah khad watershed is covered under fine administrative units. These are Bhoranj, Tauni Devi, Bijari, Hamirpur, Nadaun. Early the area was covered by four blocks Tauni devi Block is newly constituted block which was constituted in 2000. Bhoranj block cover $65.179 \mathrm{Sq} \mathrm{Km}$. Area which is $18.844 \%$ of the total area, Hamirpur covers an area of 77.258 Sq. Km. area which is $22.336 \%$, Tauni Devi covers $64.455 \mathrm{Sq} . \mathrm{Km}$. area which is $18.634 \%$, Bijri block covers 52.695 Sq. Km. Area which is $15.235 \%$ and, Nadaun block covers 86.302 Sq.Km. area which is $24.951 \%$ at the total area drained by Kunah khad. In all there are 564 villages in the Kunah Khad watershed area which is $34.86 \%$ of the total village of the district having total number of villages 1618 . This shows that area is thickly populated.

\section{Data and Methodology}

The present study is based on the primary and secondary data. Primary data collection involves, observations, visits, questionnaire, personal contact .Data is collected for different times over the period of study. Collection of Secondary data has been done from published and unpublished sources both from official and non official institutions and departments. Secondary data is collected from the toposheets, $53 \mathrm{~A} / 5,53 \mathrm{~A} / 6$, $53 \mathrm{~A} / 10$, census hand books, Tehsil offices records, Block offices records, Libraries, Remote sensing call Shimla.

Methodology: The methodology adopted in the present study is based on some analytical analysis. Delineation of kunah khad watershed. Mapping of study area from the top sheets \& land sat imageries. Verifying study area in the field. Collection of different morph metric parameters. Preparation of maps. Verifying forest cover and land use pattern by sampling method. Tabulation of socio- economic data and resource endowments. 
Terrain is a piece of land having certain physical and culture attributes. Among the physical attributes the most important are relief, drainage, geology, soil, climate etc. Following method are used to calculate the different physical attributes of a basin . The basin morpho-metry includes the analysis of the characteristics of linear and areal aspects of a watershed. Different methods of morpho-metric parameters such as _ stream ordering ( Strahler, 1964), bifurcation ratio( Schumm, 1956), Sinuosity indices, S.A. Schumm 1963, Horton Form factor F 1932, Relative relief, Dissection index,

\section{Physico -Cultural Endowments}

Introduction: Kunah Khad is a left tributary of river Beas. It covers an area of about 345.889 sq. Kms. Whole

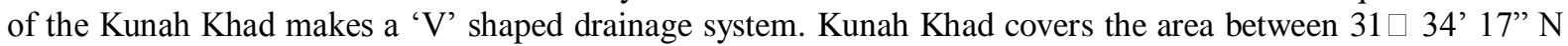
to 3146 ' $36^{\prime \prime}$ N latitude and $7620^{\prime} 59^{\prime \prime}$ e to $7640^{\prime} 31^{\prime \prime}$ e longitudes. River is $49.99 \mathrm{kms}$ long from its origin to its confluence. The maximum width of the catchments is $17 \mathrm{kms}$. River runs in south west direction in the upper catchment area and then in North West direction in the upper catchment area and then in North West direction in the middle and lower catchment area.

Drainage structure: Kunah khad watershed presents a dendritic drainage pattern. No of small tributaries are large in numbers in the middle course than in the upper and lower course of the river. Kunah khad is joined by many small and large tributaries from both sides. The main right hand side tributaries are Hathli khad, Gasoti khad, and Rain khad. Main left hand tributaries are Sukar khad. Many small tributaries join the watershed from both the sides.

\section{Sub division of watershed:}

\section{Kunah khad is divided into 6 sub watersheds these are.}

Kunah khad (upper), Gasoti, Hathli, Kunah khad (middle), Suker, Kunah khad (lower). Each sub watershed is further subdivided into micro watersheds. Upper sub water shed is divided into 7 micro watersheds. Gasoti sub watershed is divided into3 micro watersheds. Hathli sub watershed is divided into 3 micro watersheds. Lower Kunah khad sub watershed is decided into 8 micro watersheds. Each watershed or micro watershed is separated from the other by small ridges or hillocks.

Stream ordering: One of the important aspects of linear basin morpho-metric analysis is stream ordering. Stream ordering refers to the determination of the hierarchical position of a stream within a drainage basin. In the kunah khad drainage basin area there are 794 first order streams, 189 second order streams, 42 third order streams, 11 fourth order streams, 2 fifth order streams and one sixth order stream(Fig.1)

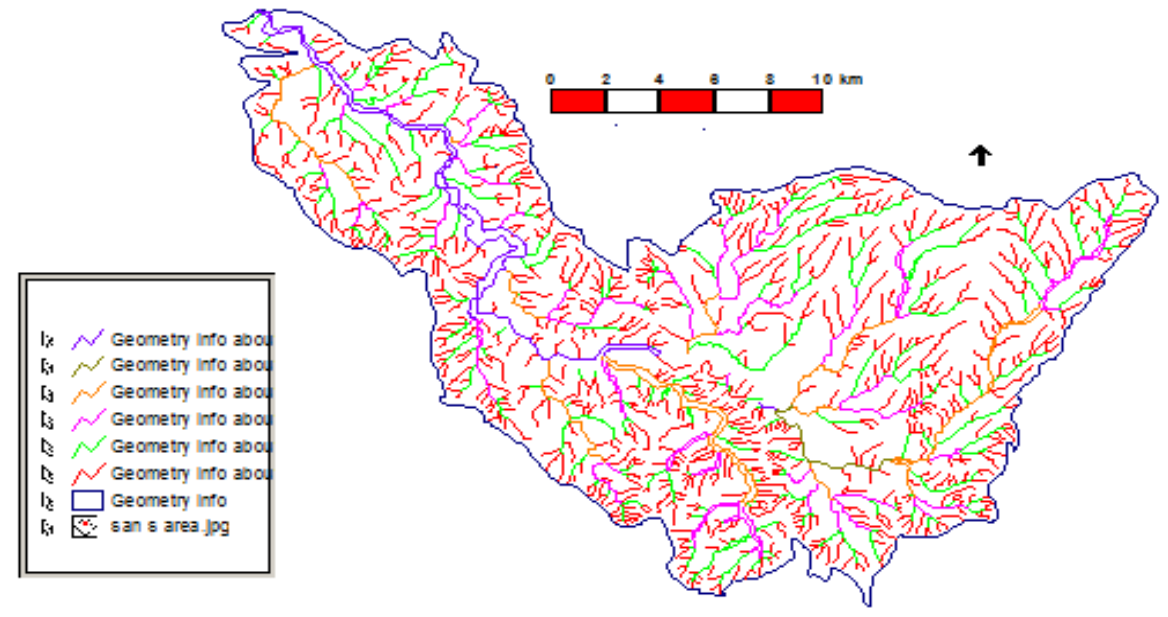

Fig. 1

Bifurcation ratio $\mathbf{R}_{\mathbf{b}}$ : Bifurcation ratio is related to the branching pattern of the drainage network. Following table show the bifurcation ratio of Kunah Khad basin. Mean bifurcation ration value of 4 shows that the area is hilly with dissected basin(Table 1). In the Kunah Khad basin bifurcation ratio increases with increasing stream order up to fifth order. Bifurcation ratio around the mean value shows that there is uniform geological structure and lithologies. The variation in the bifurcation ratio is due to environmental factor or morpho-metric control of the basin itself (Savindra Singh at. al 1984). 


\begin{tabular}{|lcc|}
\hline Stream Order & No Of Streams & Diffraction Ration \\
\hline & 793 & 4.2 \\
2 & 189 & 4.5 \\
3 & 42 & 3.8 \\
4 & 11 & 5.5 \\
5 & 2 & 2.0 \\
6 & 1 & \\
\hline \multicolumn{4}{c}{ Average bifurcation ratio= } \\
\hline
\end{tabular}

Table: 1. BIFURCATION RATIO OF KUNAH KHAD

Sinuosity indices: Sinuosity indices explain the hydrological and topographical characteristics of drainage basin. In fact, no river, in practice, shows straight path. There ere many factors that causes the river to deviate from the path. These factor may be geological and hydrological, slopes, relative relief etc.

Channel sinuosity $=\mathrm{O}_{\mathrm{L}} / \mathrm{E}_{\mathrm{L}}$

(S.A.Schumm 1963)

$\mathrm{O}_{\mathrm{L}}=$ Actual path of kunah khad. $\quad \mathrm{E}_{\mathrm{L}}=$ Expected straight path of kunah khad.

Sinuosity index value of 1.66 for the Kunah Khad shows that the channel sinuosity is transitional

Geometry of Basin shape: Basin area is very important morpho-metric attribute as it is related to the spatial distribution of a number of significant attributes. The geometry of basin shape is of significant importance. The ideal drainage basin is usually of pear shape but since it is dependent on the size and the length of the master stream of the basin and basin perimeter, which are themselves dependent on other variables such as absolute relief, slopes, geological structure and litho logical characteristics etc.

Kunah khad has value of 0.282 . The value suggests that the shape of the basin is elongated.

RELIEF: Maximum area is between the heights of 700-900 metres above mean sea level(Table 2). Only $0.893 \%$ area is above the height of 1100 metres (Fig. 2). About $14.264 \mathrm{sq} \mathrm{km} \mathrm{(4.1245)} \mathrm{area} \mathrm{is} \mathrm{between} \mathrm{the}$ height of 1100 and 1000 meters which is found near the origin of the kunah khad about $13.691 \%$ (47.356 sq $\mathrm{kms}$ ) of the area is found between the height of 1000-900 metres. Maximum area of the kuhan khad is between the heights of $900-800$ meters. About $27.800 \%$ (96.1589 sq kms) of the area is under this category. Height of 900 to 800 metres spread from the northern side of the kunah khad to the eastern side and then to the southern side of the basins. A hillock of height more than 800 is found in the middle part of the basin. About $21.058 \%$ ( $72.837 \mathrm{sq} \mathrm{kms)}$ of the total basin area is found between the heights of 700 to 800 meters. This height is found in the southern and eastern part of the basin.About $15.058 \%$ ( 52.084 sq. kms) has altitude between 600 and 700 . About $16.470 \%$ (56.968 sq kms) of the kunah Khad basin has altitude between 500 and 600 metres. Low altitude of 500 and 600 metres is found in the Nadaun block only that too is in the lower part of the basin. Only $0.906 \%$ (3.133 sq kms) of the basin area is below the height of 500 metres. Minimum height is found in the area of confluence of Kunah khad with Beas River where the flow of river becomes slow.

Relief of Kunah Khad

\begin{tabular}{|llrr|}
\hline Sr. No. & Height (Metres) & Area & \% Age \\
\hline 1 & Above 1100 & 3.089 & 0.893 \\
2 & $1100-1000$ & 14.264 & 4.124 \\
3 & $1000-900$ & 47.356 & 13.691 \\
4 & $900-800$ & 96.158 & 27.800 \\
5 & $800-700$ & 72.837 & 21.058 \\
6 & $700-600$ & 52.084 & 15.058 \\
7 & $600-500$ & 56.968 & 16.470 \\
8 & Less Than 500 & 3.133 & 0.906 \\
\hline & Total= & 345.889 & 100.000 \\
\hline
\end{tabular}




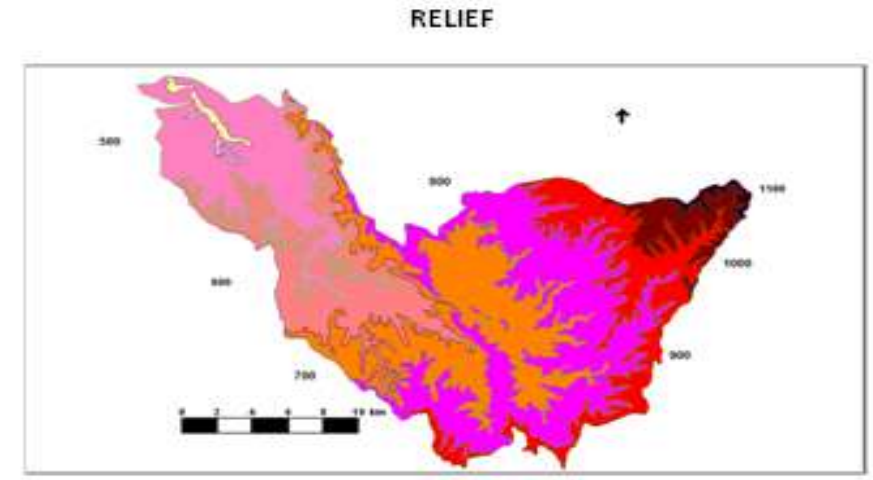

Fig. 2

Slope: Slope is one of the important aspects of morph metric analysis. The factor influencing slope developments are numerous. Lithology, tectonic characteristics and age of rocks are some of the important factors. Climate, vegetation are some other secondary factors. Slope is related to angles to inclination and inclined surface. The study of slope in geomorphology is given more importance because not only slopes do comprise greater part of the drainage system. They provide sediments to streams. Therefore hill slopes are an important component of the complex landscape that form the drainage basin ( R.J.Chorley et al 1985). Slope analysis of kunah khad is shown in figure 3. It is clear from the figure that higher slopes are present in areas where mid ridges are present and soil is loss and erosion is higher. There is a mid ridge in the watershed area where the slope is higher.

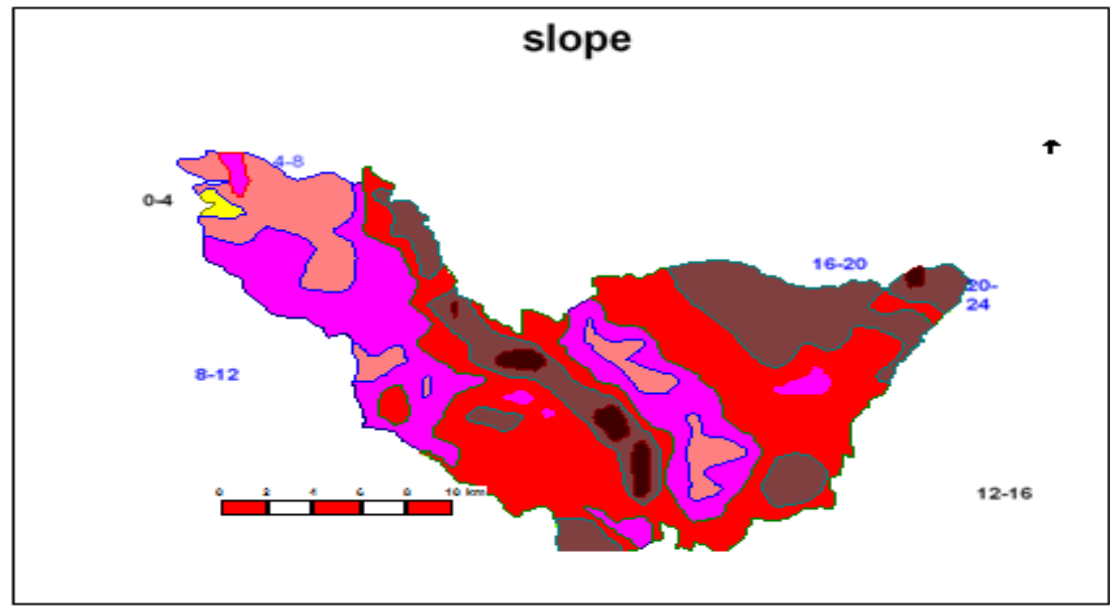

Fig. 3

It is clear from the above table that maximum area of the basin in gentle moderate and steep slope categories. Level slope is found in areas where kunah khad makes its confluence with Beas River. Only 1.673 sq $\mathrm{km}(.484 \%)$ of the area has level slope of 0 to 4 degree(Fig. 3), $41.443 \mathrm{sq} \mathrm{kms}(11.982 \%)$ of the basin area has slope of 4 to 8 degrees that too is in the lower and middle part of the basin area. This slope is very gentle and is present in and around Hamirpur town and in the Rail Bada area. About $85.898 \mathrm{sq} \mathrm{kms} \mathrm{(24.834 \% )} \mathrm{of} \mathrm{the} \mathrm{total}$ basin area of the kunah khad has gentle slope of 8 to 12 degrees. Maximum area is covered by moderate slope of $12-16$ degrees. About $136.256 \mathrm{sq} \mathrm{kms} \mathrm{(39.393 \% )} \mathrm{of} \mathrm{the} \mathrm{area} \mathrm{is} \mathrm{under} \mathrm{moderate} \mathrm{slope} \mathrm{which} \mathrm{found} \mathrm{in} \mathrm{the} \mathrm{middle}$ and lower upper part of the basin. Steep slope of 16 to 20 degrees cover an area of $73.994 \mathrm{sq} \mathrm{kms}(21.292 \%)$ of the area. Steep slope is found in areas of high altitude and in the middle part of the basin of kunah khad where a ridge bisects the drainage basin of kunah khad. This ridge is known as Dain Hamirpur ridge. Very high slope of 20 to 24 degrees is present in areas in of Dain Hamirpur ridge where kunah khad cross this ridge making a gorge in the ridge. About $6.625 \mathrm{sq} \mathrm{kms}(1.95 \%)$ of the area has very steep slope of 20 to 24 degrees. Very high slope is also associated with high drainage density, Dissection index, ruggedness and very high Relative Relief.

Relative relief: Relative relief is also termed as amplitude of available relief or local relief. Figure 4A show the relative relief of kunah khad basin. Following table show the area and \% age of area in different categories of relative relief. 


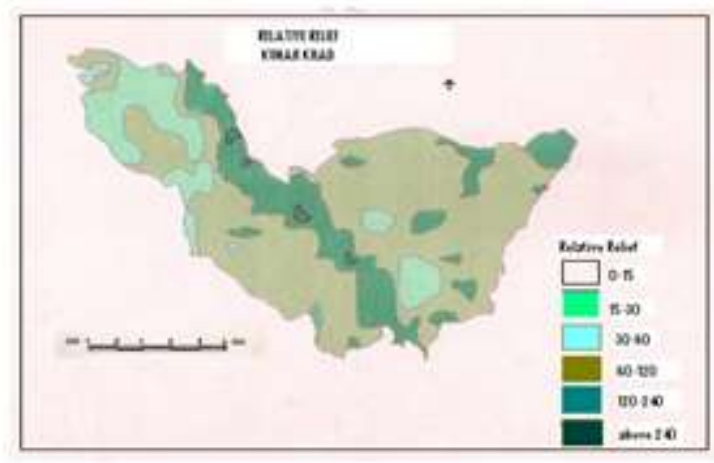

A

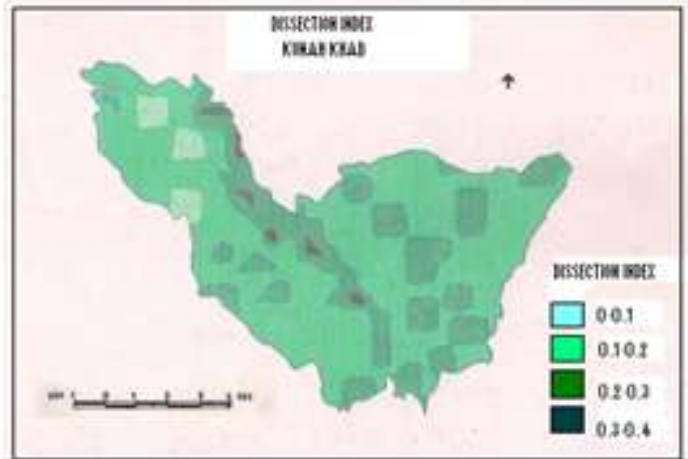

Fig. 4

B

Relative relief show the difference between the highest and lowest points in the basin area. Extremely low and moderately low values of relative relief are not present in the kunah khad basin area. Low relative relief value of 30 to 60 metres covers an area of 50.752(14.673\%) sq kms. Low relative relief $(73.746 \%)$ is found in the lower basin area of kunah khad. Moderate relative relief of 60-120 metres is found in 212.08 sq kms (61.315) of the kunah khad basin area. Moderately high relative relief is found in 81.052(23.433\%) of the area. moderately high relative relief is found in the mid basin Dain-Hamirpur ridge where the difference between the highest point and the lowest point is higher. Moderately high relative relief is found in the middle and upper part of the basin. High relative relief of more the 240 metres is found in $2.005 \mathrm{sq} \mathrm{kms}(0.579 \%)$ of the kunah khad area . If we associate relative relief with the slope of the area then it is clear that steep slope areas have high relative relief.

Dissection index: Dissection index is an important morph-metric indicator of the nature and magnitude of dissection of terrain. Dissection index of kunah khad is shown in the figure 4 B. Less dissected terrain is found in the lower part of the basin. About $17.264 \mathrm{sq} \mathrm{km} \mathrm{(4.991 \% )} \mathrm{of} \mathrm{the} \mathrm{basin} \mathrm{area} \mathrm{has} \mathrm{dissection} \mathrm{index} \mathrm{very} \mathrm{low} \mathrm{(0}$ to 0.01 . About $238.830 \mathrm{sq} \mathrm{kms}(69.048 \%)$ area has low Dissection index of 0.1 to 0.2 which is about 69.048 per cent of the total basin area. Low Dissection index is found all over the basin area except the mid basin ridge. Moderate Dissection index of 0.2 to 0.3 is found in $84.340 \mathrm{sq} \mathrm{kms}(24.384 \%)$ of the basin area. Moderate dissection index is found in the upper middle basin of the kunah khad. High dissection index covers an area of $5.455(1.577 \%)$ of the area that too in the mid basin ridge of Dain Hamirpur in the kunah khad basin.

Ruggedness number : Very low raggedness number of less than .1 is found in Bhoranj, Tauni Devi and Nadaun block area. About 117.171sq kms(33.875\%)area of the kunah khad basin has very low ruggedness number (fig.5A). Maximum area (171.205 sq km) has low ruggedness number between .1 and .2. It is about $49.498 \%$ of the total area of the kunah khad. It is found mainly in the mid of the basin area. About $45.708 \mathrm{sq} \mathrm{km}$ (13.215\%) of the area has moderate ruggedness number of 0.2 to 0.3 which I mainly found in mid ridge of the basin and near the origin of the river. Only $6.519 \mathrm{sq} \mathrm{kms}(1.884 \%)$ of the basin area has moderately high ruggedness of 0.3 to 0.4 . About $4.106 \mathrm{sq} \mathrm{kms}$ and $1.187 \%$ of the area have high ruggedness number of 0.4 to 0.5 . Only $1.180 \mathrm{sq} \mathrm{kms}(0.341 \%)$ of the kunah khad watershed has very high ruggedness number between 0.5 to 0.6

RUGGEDNESS

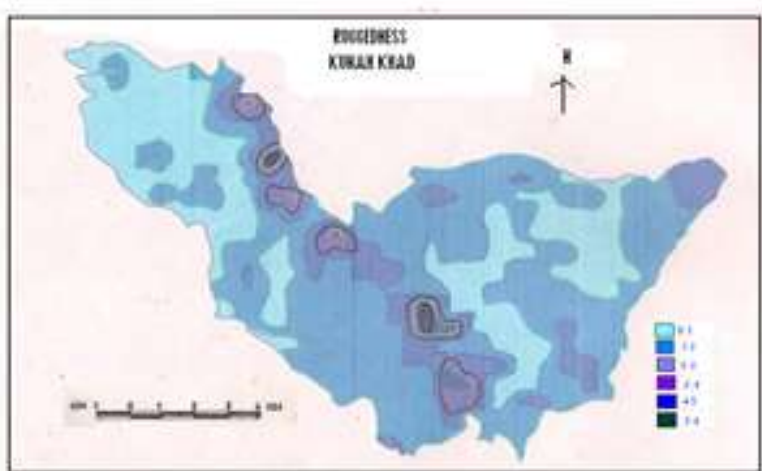

A
Drainage density

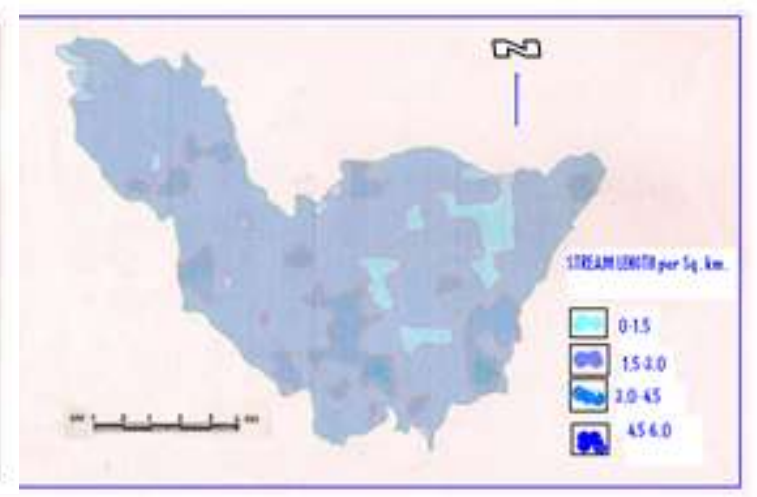

Fig. 5
B 
Drainage density: Drainage frequency is the ratio of total length of all stream segments in a given drainage basin to the total area of the basin It is also termed as stream length per square of kilometres. It is clear from the figure 5B, that low drainage density cover only $28.256 \mathrm{sq} \mathrm{kms}(8.169 \%)$ of the basin area. Moderate drainage density is present over 270.576 sq. kms (78.228\%) of the kunah khad basin. Low drainage density is present in mostly Tauni Devi Block area where hard rocks, conglomerates are present. High drainage density of 4-6 per sq. miles is present on $43.267 \mathrm{sq}$. Kms $(12.508 \%)$ of the basin area . High drainage density is present in those areas where slope is also high and erosion of the land is rapid. About $34 \%$ of the area in this category falls in the Sukar Khad sub watersheds .Very high drainage density is also present in Sukar Khad area where slope is very high and rill, gully erosions are common features. About $3.79 \mathrm{sq} \mathrm{kms}(1.095 \%)$ of the area has very drainage density.

Climate: Kunah khad basin experiences a rhythm of seasons with reversal of prevailing winds. The reversal is regularly felt twice during the year. From June to October, winds blow from south east direction when they are oceanic in origin, whereas from November to May wind blow from North West direction and are continental in character. This complete reversal of direction of winds on a gigantic scale between summer and winter is responsible for monsoons. Climate is of sub-tropical type.

Temperature: The monsoons current are the out come of changes in temperature which tend to setup surface pressure difference. Hottest months of the year are May and June. The mean temperature during these months is 32.3 and $31.7^{\circ} \mathrm{c}$ respectively. The extreme maximum temperature of the month is recorded as $42.2^{\circ} \mathrm{c}$. Extreme minimum temperature is recorded is $0^{0} \mathrm{c}$.

Moisture and humidity: The principal factor that determines the potentiality of rainfall is the humidity level in the atmosphere. Humidity is high in the months of June, July August, September, December and January if winter monsoon is on time. The temperature during these months shows a decline from the normal temperature. The winds are dry during the rest of the year and the relative humidity is comparatively low.

Rainfall: Eighty four per cent of the annual rainfall is received from the summer monsoon between June and September. About $12 \%$ of the annual rainfall is received from winter monsoon. Rainfall during the other months is scanty and sporadic. The annual rain fall of the area is about 1237 millimetres, but it is unevenly distributed over the area. At micro scale rainfall is also varied. More rainfall occurs in the southern part of the basin than in the northern eastern part of the basin. Western part also receives more rainfall.

In all there are 564 villages in the Kunah Khad watershed area which is $34.86 \%$ of the total village of the district having total number of villages 1618 . Of the total villages $52 \%$ villages are located in the slope area of more than 12 degrees. This shows that area is thickly populated. Out of the five administrative areas in which the area of kunah khad is present, the density is highest in the Tauni Devi and Bhoranj blocks followed by Nadaun (Fig. 6). The density of population is lowest in Bijri block. The sex ratio is more than 1000 in all the five blocks in the region. There were about 120 water mills ( Gharats) in the Kunah khad watershed area. Due to the excessive and illegal mining the water level in the khad has gone down. And at present only about 15 water mills are working. The area is well connected by the road to the other areas. The road density is high in the area. Almost all the villages in the region have portable dinking water facility available. There are two main crops wheat and maize in the upper catchments. Middle and lower area have three main crops namely wheat, maize and rice.

\section{Watershed Development}

Water is a prime natural resource, and a precious natural asset .It is a basic human requirement. Availability of water is highly uneven in terms of both space and time. Water management need grater understanding of the area in which it flows. It may be useful to consider water management is possible only if we manage the land properly in which water flow through channels. Land can be managed properly only when we develop man. Man can not be developed without land and land cannot be developed without water. All these three factors are interrelated to each other and dependent on one another. Therefore we should have an area which should have some common properties in relation to land water and human resources or physical \& cultural properties. For the purpose we require a watershed. A watershed is an area having common drainage. This means that the rain water falling on an area within a ridge line will flow out of this area through a single point. In a watershed the area is inter- dependent in terms of physical \& cultural aspects. In a watershed soil type, slope, vegetation cover, grass cover, drainage and its chrematistics, geology and other physical chrematistics are need to be studies with the cultural aspects of the region. If a watershed is well managed for the water, it is best managed for all the other resources. 
Watershed development is important for the overall development of an area. The physical and climatic conditions in India vary to a large extent. Stable agriculture was a dream when watershed development was started. Now it is not the situation. People have realized that they can survive only of they follow all the techniques in integrated manner. The techniques can be summarized as : Grassland development, Gully Plugs, Tree plantation and contour trenching on hill tops and slopes, Contour bunding, Water conservation structures, Lift irrigation schemes, Land leveling etc. Purpose of watershed development is to use local resources for betterment of the villages with less external input. Watershed development has raised living standard of the people in villages. People from rural area can get economical returns from agricultural lands, waste lands, lands along hill slopes. They can grow grass in hilly area and can use that as a fodder for cattle. Farmers can go for dairy development. Marginal farmers and landless can start small primary industry like that of compost. On common land village as a whole can work for grassland development and trenching with the intention that this work will increase water availability in their wells and to stop further degradation of the common or government land. For soil and water conservation this activity will help. Plantation on common land will satisfy basic need of fuel wood, fruits, fodder etc. In short by adoption of this technique there is assured drought proofing, stabilized agriculture and improvement in living standard. For adoption of this technique first step for the villagers should come together and decide what the plus are and minus points of this technique with reference to concerned village. As watershed development is not a single point technique, the priorities of different works need to decided. Important part in this type of work is to identify appropriate types of works under the existing conditions. Right choice of work and place ensures the success. Say for example tree plantation is an important activity of watershed development then choice of the species is an important part. We have to choose trees which will satisfy basic needs of a village, like fruit, fodder, fuel, improvement of soil etc. The results of successful implementation are: 1. Soil along the sloppy fields is protected from erosion. Thus work of soil conservation is done without much special hi- tech technique. Increase in the fertility of soil reducing overall requirement of fertilizer. 2. Biomass generated can be used for cattle as fodder and compost as organic manure thus requirement of chemical fertilizer is reduced. 3. As flowing water is obstructed, rate of infiltration is increased. There is good recharge of groundwater table. 4. Income level from eroded land increased when treated with different techniques. 5. Income generation from the trees in the form of fodder, nitrogen in the soil, fruits, fuel, green manure etc. 6 . Drought proofing conditions created in a village. 7. In villages employment generation increased. People in the developed villages offered employment to the people in the nearby villages. It is very difficult to convince people for watershed development work. People are not aware of their hidden potential. It is a general impression that development activity is a job of government and people have no say in it. People are not ready to spend money because of their limited resources. In initial stages, there are doubts about success and so the people are hesitant. Though overall cost required for watershed development is large, it is possible to prepare a phased programme with priorities, after discussions with the beneficiaries. Factors contributing success are: 1 . Local techniques, easy to adopt. 2. Some techniques are low cost. 3. External input to the village is minimum. 4. Participation of villagers in each and every stage of implementation of the programme. 5. Some financial assistance to the villagers from state government and from voluntary agencies working there. 6. Employment generation during implementation period and thereafter people got fully engaged in agriculture activities in their own fields. Their gain is sufficient for their livelihood. 7. Whole work is done considering village as a unit. People from rural area can get economical returns from agricultural lands, waste lands, lands along hill slopes. They can grow grass in hilly area and can use that as a fodder for cattle. Farmers can go for dairy development. Marginal farmers and landless can start small primary industry like that of compost. On common land village as a whole can work for grassland development and trenching with the intention that this work will increase water availability in their wells and to stop further degradation of the common or government land. For soil and water conservation this activity will help. Plantation on common land will satisfy basic need of fuel wood, fruits, fodder etc. In short by adoption of this technique there is assured drought proofing, stabilized agriculture and improvement in living standard. People and their environment are interdependent. Any change in the surrounding environment directly affects the people living therein. A degraded environment results in a degraded quality of life of the people. Thus efforts to reduce poverty and improve the standard of living of the people must aim at improving the environment they live in. The environment does not recognize people determined administrative boundaries. A watershed provides a natural environmental unit for planning a developmental initiative. Watershed development refers to the conservation, regeneration and the judicious use of all the resources - natural (land, water, plants, and animals) and human within a particular watershed. Watershed management tries to bring about the best possible balance in the environment between natural resources on the one side, and human and other living beings on the other. The environment is a living space on which the human community living within that area depends on for its livelihood. When the economic condition of a community deteriorates it leads to over-exploitation and degradation of natural resources which, in turn, further exacerbates poverty. It is thus necessary for people to see the relationship between their poverty and the degraded environment they live in. Thus, just as human beings 
and their activities are the cause of environmental destruction, it is only they who can restore to health the ruined environment. Hence there can be no sustainable natural resources management unless it involves the participation all the inhabitants of the concerned environment / area in an active manner.

\section{References}

[1] Chorley, R.J., S.A. Schumm and D.E. Sugden, 1985: Geomorphology, Methuen and Co. Ltd., London, New York.

[2] Gautam ,N.C, Dr V Raghavswamy, Dr R. Nagaraga, Dr. G.R.Shankar, Dr P.R Mohan 1995 concept and delineation of watershed for development, Annals, National Association of Geographers India, Val.15 No 1 PP. 53.74

[3] Horton, R.E., 1932: Drainage basin characteristics, Trans. Amer. Geophys. U. Vol. 14, pp.350-61.

[4] Schumm, S.A., 1956: The evolution of drainage systems and slopes in badlands at Perth Amboy, New Jersey, Bull. Geol. Soc. Amer. Vol. 67. pp. 597-646.

[5] Schumm,S.A., 1963 : sinusity of alluvial rivers on the Great Plains, Bull. Geol. Soc. Amer. Vol. 74, pp 1089-1100.

[6] Singh, Savindra, S.S. Ojha and S.P.Agnihotri, 1984 : On the regional variations in the bifurcation ratio, in Geographical Mosaic, edited by S.C. Mukhopadhyay, Calcatta University, pp. 203-210.

[7] Strahler,A.N., 1964 : Quantitative geomorphology of drainage basins and channel network, in Handbook of Applied hydrology (Edited by V.T. Chow0, pp. 4.39-4.76. 